\title{
Compliance issue of ready-made garments industry in Bangladesh: A case study
}

\author{
Bishwajit Das 1, ${ }^{*}$, Padma Kishore Dey 2, Md. Mehedi Hasan Sumon 1, Ahmadullah 1, Amirul Islam 1, Priyati \\ Mukherjee ${ }^{1}$ and Kazi Mumtahin Afroz ${ }^{1}$
}

${ }^{1}$ Department of Apparel Engineering, Textile Engineering College, Noakhali, Bangladesh.

${ }_{2}^{2}$ Department of Yarn Manufacturing Engineering, Textile Engineering College, Noakhali, Bangladesh.

Global Journal of Engineering and Technology Advances, 2021, 09(01), 001-010

Publication history: Received on 03 September 2021; revised on 08 October 2021; accepted on 10 October 2021

Article DOI: https://doi.org/10.30574/gjeta.2021.9.1.0135

\begin{abstract}
The aim of this research is to look into the current situation and difficulties that the compliance department faces in ensuring compliance in Bangladesh's Ready Made Garments industry. Data are gathered using a formal questionnaire from the compliance department of the garments industry, which is in charge of addressing compliance concerns in the workplace. According to the report, the garments industry faces the least difficulty in removing child labor in the workplace, followed by welfare services, workplace protection, workplace conditions, health care, and so on. The garments industry has found that freedom of association, workplace health and safety training, violence and bullying, and extended working hours are the most difficult issues to deal with inside factory premises. It also shows that the most significant obstacle for top management in implementing enforcement is a lack of top-level funding, which is accompanied by a lack of worker knowledge of their rights, a lack of government involvement, and inadequate worker literacy. The results suggest that the garment owners need to change their mindset from pure benefit to a long-term enterprise focused on justice and quality. Governments, non-governmental organizations, and labor unions all have a role to play in informing employers of their interests. Via preparation, dialogue, and fair and periodic inspections, the government should show a firm commitment to enforcing the laws.
\end{abstract}

Keywords: Ensuring compliance; Awareness of the workers; Sustainable business; Bangladesh

\section{Introduction}

Compliance, according to the Cambridge dictionary, is the act of obeying a certain law or regulation, or of behaving in accordance with an arrangement. Compliance, according to the Business Dictionary, is the certification or affirmation that the person who performs an operation (such as the writer of an audit report), or the manufacturer or provider of a good, complies with agreed procedures, laws, established rules and regulations, defined specifications, or contract terms. As a result, compliance is the act of adhering to rules, laws, and/or legislation. Organizations must ensure that they are in accordance with vendor-set software license terms, as well as regulatory mandates. It means adhering to a set of rules, such as a specification, protocol, standard, or statute. Regulatory enforcement is the aim that companies strive for in their attempts to ensure that they are mindful of and follow all applicable rules, legislation, and regulations [1]. Organizations are gradually using consolidated and harmonized sets of regulatory controls as the number of laws grows and the demand for organizational accountability grows. This method is used to ensure that the relevant governance criteria are fulfilled without duplicating initiative or activity. Garments enforcement refers to the adherence to such industry requirements by staff and officers. Employees in the textile industry are likely to operate in a mild setting. These compliances or guidelines are required to run a business. Since 1978, Bangladesh has been a major player in the RMG (Ready Made Garment) industry. Textiles and garments account for about $85 \%$ of Bangladesh's gross export earnings. 85 percent of the total comes from the garment industry, which includes knit and woven ties, blouses, dresses,

\footnotetext{
* Corresponding author: Bishwajit Das

Department of Apparel Engineering, Textile Engineering College, Noakhali, Bangladesh.

Copyright (C) 2021 Author(s) retain the copyright of this article. This article is published under the terms of the Creative Commons Attribution Liscense 4.0.
} 
skirts, jeans, coats, sweaters, sportswear, and a variety of other casual and fashion products. About 4.6 million people work in the industry, the majority of which are women from low-income families. The staff, which includes sewing assistants, aides, cutting masters, pattern designers, and finishers, is critical in the fashion industry. Bangladesh has a large and inexpensive labor force that can be quickly trained and converted into semi-skilled and skilled workers. The existence of such a group is one of the benefits that Bangladesh will enjoy in the form of international textile exchange for a long time. Due to the lack of expertise and knowledge of garment manufacturers involved in the trade, the quality of products shipped from Bangladesh has often been doubted by international buyers. In order to export readymade garments, not only are quality parameters important for acceptance of the product as intended end use, but also the working environment in which the garments are to be produced is equally important to ensure that the sweatshop concept is completely avoided and the code of conduct is stretched towards achieving the social compliance objectives. The central fields of social responsibility are focused on universal human rights values, as well as local history and practice. The system's main goal is to secure human rights in the ready-made garment industry. As a result, Bangladesh faces a significant challenge in meeting global consumer demand [2].

\section{Objectives of Compliance in Garments Industry}

- To provide a high-level rundown of the current enforcement issues.

- To be aware of several forms of regulatory matters.

- To provide an outline of the current state of compliance management in Bangladesh's ready-made garment factories.

- Determine whether current RMG compliance control practices are acceptable to employers and workers.

- To learn more about the challenges and opportunities of compliance management in the ready-to-wear clothing industry.

- $\quad$ Ensure that garments comply with human rights in the ready-made garment industry.

In this paper, in section II the review of the existing work relevant to this proposed model is presented. In section III introduces the methodology. Section IV presents the result and discussion while V concludes the paper.

\section{Literature Review}

Compliance means conforming to a rule, such as a specification, policy, standard or law. Organizations are increasingly adopting the use of consolidated and harmonized sets of compliance controls. This approach is used to ensure all necessary governance requirements can be met. One of the first was in 1992, when an article in the Washington Post about the manufacture of Levi Jeans by Chinese prison labor on the island of Saipan sparked a public outcry. Levi Strauss responded quickly by creating a code of labor standards (compliance) for all of its international suppliers [3]. In 1993, Wal-Mart, a major US retailer, was one of the first to create a detailed code.

Here is a compilation of enforcement points, some of which are entirely maintained and others which are only partly maintained. The following points are especially applicable to the garment industry [4]

- Compensation for holiday

- Leave with wages

- Health register

- Time care

- Accident register

- Workman register

- Equal remuneration

- National festival holiday

- Overtime register

- Labor welfare

- Weekly holiday fund

- Sexual harassment policy

- Child labor abolition policy

- Anti-discrimination policy

- Zero abasement policy

- Working hour policy

- Hiring / recruitment policy 


\begin{tabular}{|ll|}
\hline & Environment policy \\
$\square$ & Security policy \\
$\square$ & Buyers code of conduct \\
Health and safety committee & Canteen \\
\hline
\end{tabular}

There are various forms of compliance standards available. CSR (corporate social responsibility) [5] is a self-regulatory business model that allows a corporation to be socially responsible - to itself, its stakeholders, and the general public. Companies should be mindful of their effect on all facets of society, including economic, social, and environmental, by exercising corporate social responsibility, also known as corporate citizenship. CSR refers to a company's decision to operate in ways that benefit society and the community rather than harming them in the ordinary course of business.

WRAP [6] was formed out of the desire to create an independent and objective body to help apparel factories verify that they are operating in compliance with local laws and internationally-accepted standards. WRAP has grown to become a global leader in social compliance and a trusted independent supply chain partner for dozens of companies around the world. There are currently over 2,200 WRAP-certified facilities found throughout the world employing over 2 million workers. According to a 2010 UNIDO Study, Making Private Standards Work for You, WRAP is the "standard most often cited" for social compliance certification in the textile sector. The first Board of Directors was named in 1999 and WRAP was officially incorporated in 2000. The majority of the Board is comprised of individuals not affiliated with the industry.

The Fair Wear Foundation (FWF) [7] is a non-profit organization that partners with textile brands, staff, and industry influencers to improve working conditions in garment factories. Receiving the FWF seal of approval does not mean that all established labor quality requirements are met; rather, it indicates a specified intention to improve.

SA8000 is a management system standard, modeled on ISO standards [8]. It was developed in 1989 by Social Accountability International. It measures the performance of companies in eight areas important to social accountability in the workplace. The criteria require that facilities seeking to gain and maintain certification must go beyond simple compliance to the standard. It is based on the principles of international human rights, norms as described in International Labor Organization conventions.

The Clean Clothes Campaign (CCC) [9] is the Garments industries largest alliance of labor unions and non-governmental organizations. The civil society campaign focuses on the improvement of working conditions in the garment and sportswear industries. The CCC has campaigns in 15 European countries.

The Oeko-Tex Standard 1000, published by "Oeko-Tex International - Organization for the Evaluation of Environmentally Sustainable Textiles," covers both human ecology and textile manufacturing conditions. The aim of Oeko-Tex Standard 1000 is to inspect manufacturing facilities and goods for environmental compatibility and to independently record that steps are being taken and that a certain level is being reached in the process [9].

ISO 14001 specifies the requirements for an EMS. It does not define environmental performance criteria, but rather sets out a structure for a corporation or agency to adopt in order to create an effective EMS. Any company that wants to increase resource utilization, waste reduction, and cost reduction can use it. The use of ISO 14001 will give company management and staff, as well as external stakeholders, confidence that environmental impact is being evaluated and strengthened. ISO 14001 can be combined with other management roles to help businesses achieve their environmental and economic objectives [8].

The Global Organic Textile Standard (GOTS) is the world's leading organic textile production standard, with ecological and social standards and independent certification of the entire textile supply chain [9].

Version 5.0 was released on March 1, 2017, three years after Version 4.0 was released and 12 years after the first version was released. In order to achieve a reliable and straightforward set of standards, the revision work took into account high ecological and social requirements, as well as worldwide practicability and verifiability. 
The Accord is a legally binding agreement between brands and trade unions in Bangladesh to work for a secure and stable garment and textile industry. The Accord includes factories that produce Ready-Made Garments (RMG), as well as home textiles and cloth and knit accessories, at the discretion of signatory companies [9].

The Business Social Compliance Initiative (BSCI)[11] is a business-led initiative aimed at helping businesses improve working conditions in their global supply chains. BSCI brings together hundreds of businesses under a single code of conduct and assists them in their efforts to create an ethical supply chain by delivering a development-oriented mechanism that is accessible to all industries and sourcing countries.

LEED (Leadership in Energy and Environmental Design) is a globally recognized green building certification scheme that offers third-party assurance that a building or neighborhood was designed and constructed using strategies aimed at enhancing performance across all main metrics: energy conservation, water efficiency, CO2 emissions reduction, enhanced indoor environmental quality, and more [8]

\section{Methodology}

\subsection{Factories observation}

Liz Fashion Industry Limited and Epyllion Knitex Ltd are the leading factories in Bangladesh, where a large number of repeat customers have placed orders due to their combination with compliance, which is relevant and pleasing to them[8,9]. This factory operates by combining compliance with likability to the buyer. The following are the potential combinations:

\subsection{Liz Fashion Industry Limited}

\subsubsection{Factory Profile}

Liz Fashion Industry Limited, based in Bangladesh, is a leading manufacturer of underwear, sportswear, and outerwear that exports to Europe, North America, Australia, and China. Liz Fashion's organizational framework and facilities provide the ideal vertically integrated atmosphere for ensuring superior quality across the product life cycle. We have a multi-disciplinary team of seasoned professionals in the fields of technical design, textile and apparel manufacturing, industrial engineering, quality management, merchandising, and sourcing who are focused on making our customers' products right from the start [9].

\subsubsection{Factory Code of Conduct:}

Liz Fashion Industry Limited is $100 \%$ garments manufacturing and exporting company and the management believes that human rights should be respected, valued and developed with continual improvement programs in consideration of national laws, ILO conventions and in accordance with internationally recognized standards. As a best practice, Liz Fashion Industry Limited shall apply the highest standards when differences or conflicts in any other standards arise. As such, the following are our codes:

\section{Employment Relationship (ER)}

Company shall adopt and adhere to rules and conditions of employment that respect workers and, at a minimum, safeguard their rights under national and international labor and social security laws and regulations.

\section{Non-discrimination (ND)}

Company believes that all terms of conditions of employment should be solely based on individual's ability to do the job and not on the basis of personal characteristics. All employees shall be treated in fair way without any discrimination in employment, including hiring, compensation, advancement, discipline, termination orretirement, on the basis of gender and social status, nationality, and representation of trade union, disability, political opinion or other concerns.

Non-harassment \& Abuse (NH/A)

Company recognizes the value of its employees and treats them with respect and dignity. Factory shall not use unusual disciplinary practices such as threats, or any physical, sexual, psychological or verbal! Harassment or abuse. 


\section{Forced Labor (FL)}

Company shall not allow forced labor, prison labor, indentured labor, bonded labor, or other forms of forced labor. All employees are recruited to work voluntarily. It neither accepts any kinds of forced labor nor recruits any slave worker - directly or indirectly.

\section{Child Labor (CL)}

Company shall not recruit or encourage any child at work place, nor do allow presence of children at the production sites, who are under the age of 15 or under the age for completion of compulsory education, whichever is higher. As our best practice, the facility shall employ minimum 18 years of age and above.

\section{Freedom of Association \& Collective Bargaining (FA/CB)}

Company respects and recognizes the right of employees to freely associate, to form trade unions and to engage in collective bargaining. We believe that mutual understanding will make a good relationship between employer and employee, thus will Increase productivity and to achieve a definite goal.

\section{Health, Safety and Environment (HS/E)}

Company shall maintain safe, clean and healthy environment in compliance with existing laws and regulations. We shall ensure that the workplace is free from hazards and shall abide by the health and safety standards. The facility shall continuously monitor production processes and to take steps to mitigate negative impacts that the workplace has on the environment.

\section{Hours of Work (HW)}

Company shall maintain reasonable employee work hours based on the limits of regular and overtime hours allowed by the country law. The regular working hours shall not exceed 48 hours per week but in exceptional circumstances is permissible up to 60 hours, with maximum 2 hours overtime per day for 6 days. Any overtime work shall be voluntary and shall not be requested on a regular basis which shall be paid at a correct premium rate. Employees shall be allowed at least 24 consecutive hours of rest in every seven-day period and shall be recognized as general weekend holiday.

\section{Compensation (C)}

Every worker has a right to compensation for a regular work week that is sufficient to meet the worker's basic needs and provide some discretionary income. Company shall pay at least the minimum wage or the appropriate prevailing wage, whichever is higher, comply with all legal requirements on wages, and provide any fringe benefits required by law or contract. Where the compensation does not meet worker's basic needs and provide some discretionary income, the company commits to take appropriate actions to progressively realize a level of compensation that does.

\section{Customs law and Security (CL/S)}

Company shall abide by the customs rules and regulations and shall be aware about illegal transshipment. We shall maintain a system to monitor the shipment loading process in the factory premises and to support all actions to discourage smuggling of goods. The facility shall fully participate according to the supply chain security requirement to enhance the security of the supply chain, transport and logistics system. We shall be committed to ensure the safety through normal security reasons by maintaining the safety of all employees and protecting the facility properties through controlling the access of incoming/outgoing visitors, vehicles and other contrabands.

\subsection{Epyllion Group}

Since its inception in 1994 as a house of Readymade Garments (RMG) engaged in the manufacturing and exporting of Knit Apparels, Epyllion Group has grown to become one of the largest conglomerates in the world, with a significant backward linkage in all types of knit garments, textiles, wet processing, and garment accessories. It has a cutting-edge vertically integrated garment manufacturing facility that provides customers with a one-stop shopping experience. We have developed ourselves as a significant garment manufacturer for a range of well-known European, American, and Australian brands [10]. 


\subsubsection{Ethical Standard/Code of Conduct:}

Compliance with all laws and regulations

Epyllion Group shall comply with all laws and regulations of the country where it operates and ratified international conventions.

\section{Prohibition of child labor}

Epyllion Group shall not recruit any employee below the mentioned age restricted by the local law.

\section{Prohibition of forced labor}

Epyllion Group shall not force any employees for work rather they should be given the opportunity of voluntary work accomplishment.

Hours of Work

Epyllion Group shall not require workers to work more than the regular and overtime hours allowed by Bangladesh Labor Act, 2006 and Bangladesh Labor Rules, 2015.The regular work week shall not exceed 48 hours and workers shall be granted at least 1 (one) day off for every seventh calendar day. In Epyllion worker may work up to 10(ten) hours in a day and overtime work week shall not exceed 12 hours. Provided that the total working hours of such worker shall not exceed60 (sixty) hours in a week, and on the average 56(fifty-six) hours per week in a year. All overtime work shall be voluntary. Epyllion shall not request overtime on a regular basis and shall compensate all overtime work at the rate of twice of worker's ordinary rate of basic wage.

\section{Compensation and Benefits}

Epyllion Group shall pay at least the minimum wages comply with all legal requirements (Bangladesh Labor Act, 2006, Declared Latest Minimum Wage Gazette in Bangladesh \& Bangladesh Labor Rules, 2015) on wages. The wages of a worker shall be paid before the expiry of the seventh working days following the last day of the wage period in respect of which the wages are payable. Where the employment of a worker is terminated by retirement or by his retrenchment, discharge, removal by the epyllion or otherwise, all wages payable to worker's shall be paid before the expiry of the 30 (thirty) working days following the day of termination of worker's employment.

\section{Regular employment}

Epyllion Group shall fulfill the responsibility regarding the rights of workers recognized employment relationship established through local law and practice and must try to confront the legal obligations arising from established employment relationship.

\section{Prohibition of sexual harassment \& abuse}

Epyllion Group shall provide a workplace environment which is free of any sexual and/or other form of harassment, abuse and any corporal punishment.

Equal employment opportunities and non-discrimination

Epyllion Group shall reward employee according to their individual performance. Epyllion Group will maintain the equal opportunity policy in recruitment, training and development, promotion, transfer, compensation and benefits etc. without any form of discrimination such as race, caste, color, religion, sex (including pregnancy), marital status, family status, sexual orientation, regional origin, age, disability and veteran status.

\section{Freedom of association}

Epyllion Group shall uphold the freedom of association and the effective recognition of the right to collective bargaining. All employees of Epyllion Group including in its corporate office and factories are free to join any kinds of legally approved and registered trade unions or any kinds of association.

\section{Health \& workplace safety}

Epyllion Group shall ensure healthy work environment for all. The company shall provide a safe and healthy workplace setting to prevent accidents and injury to health arising out of linked with or occurring in course of work or as a result 
of the operation of employers' facilities. Company shall adopt responsible measures to mitigate negative impacts that the workplace has on the environment.

\section{Security}

Epyllion Group shall ensure physical and personnel security of employees in work place in terms of any untoward situation. Epyllion Group shall not employ any person in a place where life can be endangered.

Respect towards employee's rights \& fairness

Epyllion Group shall adhere to all rules and conditions of employment that respect employees and maintain rights under national and international labor and social security laws and regulations.

Respect for stakeholder's interest

Epyllion Group shall recognize and have due regard for the legal rights as well as the interests of its stakeholders in supply chain and value chain and respond to their expressed concerns.

\section{Environment}

Epyllion Group shall act by country's environment act and internationally proclaimed environmental laws and standards in business operation. While doing so the core aim of Epyllion Group will be to care the nature and bring positive impact for society, environment and nation.

\subsubsection{Certification [10]}

WRAP is an independent, non-profit organization dedicated to the certification of lawful, humane and ethical manufacturing throughout the world. (Awarded in 2008, Gold Certified)

Organic Content Standard OCS BL and 100 is a standard for tracking and documenting the purchase, handling, and use of $100 \%$ certified organically grown cotton fiber (organic in conversion cotton fiber) in yarns, fabrics and finished goods. (Awarded in 2009, OCS 100 and OCS Blended, Registration No: CU 807720)

C-TPAT is a voluntary government-business initiative that builds cooperative relationships that strengthen and improve overall international supply chain and U.S. border security. C-TPAT is widely recognized as one of the most effective means of providing the highest level of cargo security through close cooperation with international supply chain businesses such as importers, carriers, consolidators, licensed customs brokers, and manufacturers. Through this initiative, U.S. Customs and Border Protection (CBP) is asking businesses to ensure the integrity of their security practices and communicate and verify the security guidelines of their business partners within the supply chain. (Awarded in 2008, Score 92.00)

Oeko-tex 100 The Oeko-Tex® Standard 100 is a globally uniform testing and certification system for textile raw materials, intermediate and end products at all stages of production. (Awarded in 2009, Standard 100 certified)

BSCI The Business Social Compliance Initiative (BSCI) is a leading business-driven initiative for companies committed to improving working conditions in the global supply chain. BSCI unite more than 900 companies around a development-oriented system applicable to all sectors and sourcing countries.

\subsubsection{CRAB Credit Rating Agency in Bangladesh}

Under capital adequacy regulatory framework (BASEL II implementation framework) of Bangladesh Bank, all the leading ventures of Epyllion Group have been awarded credit rating bearing A2 by Credit Rating Agency of Bangladesh Ltd (CRAB) for the financial year 2011-12. The latest award has been enhanced from the previously attained A3. The award expresses that Epyllion Group possess strong capacity to meet the financial commitments and judged to be very high quality subject to low credit risk.

\subsubsection{Membership}

\section{SEDEX Membership}

SEDEX, the Supplier Ethical Data Exchange, is a not for profit membership organization dedicated to driving improvements in responsible and ethical business practices in global supply chains. As the largest collaborative 
platform for sharing ethical supply chain data, SEDEX is an innovative and effective supply chain management solution, helping you to reduce risk, protect your company reputation and improve supply chain practices. (Epyllion has got in 2009, Auditor SGS)

\subsubsection{Communication on Progress}

\section{UNGC}

The United Nations Global Compact is a strategic policy initiative for businesses that are committed to aligning their operations and strategies with ten universally accepted principles in the areas of human rights, labour, environment and anti-corruption. When joining the Global Compact, companies make a commitment to issue an annual Communication on Progress (COP), a public disclosure to stakeholders (e.g., investors, consumers, civil society and Governments) on progress made in implementing the ten principles of the UN Global Compact, and in supporting broad UN development goals. (Awarded in 2012)

\subsubsection{Awards \& Recognition}

Best Supplier Award of C\&A in 2004

Certified by WRAP, Organic Content Standard OCS BL and 100, C-TPAT, Oeko-tex 100, BSCI, SEDEX, GSV, ISO 26000, and LEEDGOLD.

\section{Results and discussion}

Compliance is playing a very important role for the garment factories of Bangladesh. DBL group, Epyllion group and Liz Fashion Industry Ltd adheres to compliance standards. For following compliance standard, they create their market larger. They are getting new buyers. Factory production capacity is increasing. Workers are getting the rights they deserve. Environment pollution levels are decreasing. As a result, many more orders are being received.

There are many benefits are gain by following compliance standards. These are-

- Gets higher price of products

- Free from labor unrest.

- Satisfaction of the buyer requirement.

- Can work directly with reputed buyers.

- Have consistency in order

- Reduce worker turnover rate.

- Increased worker morality.

- Increased productivity.

- Increased product quality.

- Have global image and global recognition for their performance.

- Good public or community relation.

- Improved government-industry relation.

Compliance auditing has become an important task to ensure if the company meets standards of various environmental laws. The compliance program team with regular auditing can bring the desired change in the code of conduct, ethics and other issues based on compliance.

There are some basic areas of compliance such as-

- Proper working conditions, minimum wages \& standard working hours Non-discrimination

- Restriction on child or forced labor Freedom of association

- Environmental protection and other safety laws

Some barriers have to face by an industry to make it complaint. When the auditors of different organizations such as ISO, WRAP, and BSCI etc. come to audit they inspect all the things that are required to give the certificates. But sometimes a company failed to achieve the certificates after auditing their place. The possible reasons will be 
The Child Labor Issues -will not hire any employee under the age of 14 or under the minimum age established by law for employment, whichever is greater, or any employee whose employment would interfere with compulsory schooling.

Working Hours-Hours worked each day, and days worked each week, shall not exceed the limitations of the country's law. Organizations should provide at least one day off in every seven-day period, except as required to meet urgent business needs.

Health and Safety- Authority should provide a safe and healthy work environment. Where residential housing is provided for workers, they should provide safe and healthy housing.

Workplace Environment-Authority should comply with environmental rules, regulations and standards applicable to their operations, and will observe environmentally conscious practices in all locations where they operate and make sure they are following the safety rules. Environment should be respected.

These are the fundamental principles that should be followed by every organization. If the organizations do not obey the above rules and regulations, the auditors will give the authority some time to change the conditions before auditing the plant. They will levy a penalty if the audit fails. Some crudes, as well as subtle non-tariff barriers, obstruct free trade. It is important to remember that the goal is not Bangladesh itself, but rather the comparatively less costly apparel that Bangladesh and other developing countries can manufacture and export. For example, Indian cotton skirts were banned from US markets because they were flammable, which most Indian exporters interpreted as a non-tariff barrier. Many of these non-tariff barriers are also environmental in nature. Although the world encompasses a wide range of issues, consider the labor situation, including working conditions, salaries, and the right to organize. The Uruguay Round (UR) final act does not include any well-defined clause that binds international transactions to environmental standards. The environment is rarely listed in the Uruguay Round. However, a trade and environment committee has been formed and will be part of the World Trade Organization. There is a requirement that developed countries provide assistance. In exchange for access to rich-country markets, environmental standards should be strengthened. Not only will labor conditions such as minimum wages and safety standards need to be changed, but even broad political rights such as freedom of association and the right to collective bargaining will need to be improved to an appropriate level. On the basis of human rights, the UR acknowledges the need for standardized working conditions. Bangladesh would inevitably be disadvantaged if rich developed countries insist that salaries, working conditions, health and safety standards, and other factors in Bangladesh are too bad. The issue of the environment's comparability looms large. The view of environmental issues in rich countries differs from that of developing countries. We make a fair comparison between the environmental conditions in Bangladesh, which include factory working conditions, and the incomparable. We are not only weaker economically, but also socially, culturally, and politically. As a result, our interests would vary from those of the affluent countries, even on moral grounds. Bangladesh has a natural endowment of low-cost labor. It would be great and ideal to be able to pay decent wages to the Bangladeshi women and girls who work in RMG factories. However, what is a handsome wage in Bangladesh might not be so in Germany or the United States. Given Bangladesh's price levels, per capita income, and average living standard, paying an hourly wage of $\$ 5.00$ is neither necessary nor economically / socially tenable. If we pay RMG workers these high salaries, we would create a social inequality. The majority of domestically oriented companies would be unable to pay such high salaries.

\section{Conclusion}

Based on the collected data and study, it became apparent that social compliance roles and activities have the greatest effect on work atmosphere growth and ensure worker benefits, resulting in worker satisfaction. Compliance refers to carrying out activities or implementing procedures or policies in accordance with the criteria or demands of an external body, such as the International Labour Organization, the Human Rights Organization, or international buyer requirements, among others. Following the fire at Tazreen last November, a second fire at a garment factory in Dhaka has heightened the debate over enforcement. Thousands of workers' lives and livelihoods are at risk as a result of this. The challenge for the country's apparel industries is to maintain ties in a properly working supply chain that can feed stores all over the world without jeopardizing the country's garment staff. The Bangladesh textile industry has captured the world's attention. The extent to which the fatal fire accidents would have a detrimental effect on the entire readymade garment (RMG) sector is unknown. Concerned about labor conditions in Bangladesh, US apparel buyers are now putting pressure on RMG manufacturers in the country to ensure proper adherence to certain standards in the field. Buyers in international markets are becoming increasingly worried about the situation.

However, demand for compliance-related executives has risen unexpectedly, at a time when the RMG sector is experiencing a professional manpower shortage. Personnel with the requisite academic qualifications and relevant experience in related fields are in high demand in both RMG and non-RMG industries. The majority of the country's 
export-oriented factories are scrambling to hire 'enforcement experts.' Their overseas consumers are placing growing pressure on them to ensure safe working conditions in their factories.

\section{Compliance with ethical standards}

\section{Acknowledgments}

We will to acknowledge the efforts of my employer for given the opportunity to carry out the research work in the Textile Engineering College, Noakhali, Bangladesh.

\section{Disclosure of conflict of interest}

None.

\section{References}

[1] Regulatory compliance - Wikipedia [Internet]. En.wikipedia.org. 2021 [cited 12 October 2021]. Available from: https://en.wikipedia.org/wiki/Regulatory_compliance

[2] History of Corporate Compliance Regulations [Internet]. Lawshelf.com. 2021 [cited 12 October 2021]. Available from: https://lawshelf.com/shortvideoscontentview/history-of-corporate-compliance-regulations/

[3] History of Garments Industry in Bangladesh [Internet]. Linkedin.com. 2021 [cited 12 October 2021]. Available from: https://www.linkedin.com/pulse/history-garments-industry-bangladesh-motahar-hossain-rana

[4] shan a. THESIS REPORT ON COMPLAINCE [Internet]. Academia.edu. 2021 [cited 12 October 2021]. Available from: https://www.academia.edu/11854384/THESIS_REPORT_ON_COMPLAINCE

[5] Corporate social responsibility in textile industry - Free Industry Articles - Fibre2fashion.com [Internet]. Fibre2fashion.com. 2021 [cited 12 October 2021]. Available from: https://www.fibre2fashion.com/industryarticle/2438/corporate-social-responsibility

[6] 12 Principles - WRAP [Internet]. WRAP. 2021 [cited 12 October 2021]. Available from: https://wrapcompliance.org/12-principles/

[7] Natives D. Labour Standards - Fair Wear Foundation [Internet]. Fairwear.org. 2021 [cited 12 October 2021]. Available from: https://www.fairwear.org/about-us/labour-standards

[8] ISO 14000 - Wikipedia [Internet]. En.wikipedia.org. 2021 [cited 12 October 2021]. Available from: https://en.wikipedia.org/wiki/ISO_14000

[9] Seitenwerkstatt D. The Standard - worldwide leading for organic textile production - GOTS [Internet]. Globalstandard.org. 2021 [cited 12 October 2021]. Available from: https://global-standard.org/the-standard

[10] [Internet]. $2021 \quad$ [cited $12 \quad$ October 2021]. Available from: https://www.researchgate.net/publication/293133864_Compliance_Management_Practices_on_Readymade_G arment_Industry_in_Bangladesh_An_Exclusive_Study 